MODELOVANJE POUZDANOSTI SLOŽENIH TEHNIČKIH SISTEMA U INDUSTRIJI, SSA KONCEPT

\title{
RELIABILITY MODELING OF COMPLEX TECHNICAL SYSTEMS IN INDUSTRY, SSA CONCEPT
}

\author{
Dragan A. Milošević \\ Univerzitet „Union - Nikola Tesla“, Beograd, Srbija
}

OMESTE

JEL Category: C51, C52, C63

\begin{abstract}
Apstrakt
Rad prezentuje probleme u vezi sa modelovanjem složenih tehničkih sistema u industriji ali i mogućnosti rešavanja putem Split System Approach koncepta. Cilj rada je da se prikažu prednosti primene SSA koncepta u odnosu da druge modele. U radu je objašnjeno nekoliko vrsta složenih sistema i njihova podela prema broju i strukturi komponenata. Izvedena je i podela sistema prema popravljivosti komponenata. $U$ daljem tekstu su navedena i ograničenja modelovanja pouzdanosti složenih sistema u industriji. Navedeno je moguće rešenje u vidu semi-Markovljevih lanaca za nepopravljive komponente sistema. Izloženi su i problemi modelovanja imperfektnih akcija održavanja. Modelovanje pouzdanosti je zadatak koji najčešće ne bude adekvatno obavljen iz razloga što većina modela ne bude primenljiva ili ne uvažava realno stanje stvari. SSA model omogućuje da se ostvari kompromis između ovih zahteva. Dodatna pomoć u implementaciji SSA modela predstavljaju kompjuterske tehnologije jer omogućuju masovne kalkulacije. Složena problematika modelovanja pouzdanosti složenih tehničkih sistema u industriji najzahtevnija u domenu implementacije na brojevno složene sisteme. Nasuprot tome, da bi se došlo do kvalitetnijih podataka o pouzdanosti sistema potrebno je dekomponovanje sistema na veći broj komponenti čemu se kao ograničenje nameće neretko mali broj podataka o otkazima po komponenti. SSA koncept ima dobre osobine uz sve nedostatke kao i svaki model.
\end{abstract}

Ključne reči: složeni sistem, model pouzdanosti, preventivno održavanje

\section{Abstract}

The paper presents problems related to the modeling of complex technical systems in the industry but also odds to troubleshoot via Split System Approach concept. The aim is to show the benefits of applying

Adresa autora:

Dragan A. Milošević

奉=" prof.dragan.milosevic@gmail.com the concept of SSA compared to other models. In paper are explained several kinds of complex systems and their classification according to the number and structure of the components. It is made 
division of the systems according to the components repairability. Below are listed the limits of reliability modeling of complex systems in the industry. It is indicated a possible solution in the form of semiMarkov chains for unrepairable system components. It is exposed the problems of modeling imperfect maintenance actions. Reliability modeling is a task that usually cannot be adequately done because most of the models is not applicable or does not respect the reality. SSA model makes it possible to achieve a compromise between these requirements. Additional help in the implementation of SSA models present computer technology because they allow mass calculations. Complex issues of reliability modeling of complex technical systems in industry are the most demanding in the field of implementation for the systems with many components. In contrast, in order to reach better data of system reliability it is necessary to decomposition of the system into many of components. Limitation for that task is a small number of failures per component. SSA concept has good properties with all the disadvantages like any other model.

Keywwords: complex system, reliability model, preventive maintenance

\section{UVOD}

Problematika modelovanja pouzdanosti je fundamentalna i od velikog značaja sa funkcionisanje tehničkih sistema u industriji. Ona omogućuje definisanje ukupne sigurnosti funkcionisanja sistema ali je i indikator zdravlja mašina. Modeli pouzdanosti su neizostavni deo teledijagnostičkih aktivnosti i osnov svih akcija održavanja a time i bitan faktor finansijskih efekata poslovanja. Kao takvi modeli pouzdanosti bude veliku pažnju i istraživanjima ali mnoga od polja istraživanja su još u povoju. Primer su modeli pouzdanosti složenih tehničkih sistema koja imaju mali broj otkaza i/ili veliki broj preventivnih održavanja. Takođe dosta napora i nešto više rezultata ima $u$ domenu imperfektnih akcija održavanja kakve su realnost u industriji. Ipak, složenost problema daje mogućnosti modelovanja koje uvek imaju nedostataka u odnosu na realnost na terenu.

\section{VRSTE SLOŽENIH TEHNIČKIH SISTEMA}

Kada govorimo o složenim tehničkim sistemima u industriji možemo razgraničiti vrste složenosti koje konsekventno utiču na modelovanje pouzdanosti, pa se prema tome i razlikuju:

- brojevno i

- strukturno složeni tehnički sistemi.

Brojevno složeni sistemi su oni koji imaju veliki broj istih elemenata. Primer je transportna traka koja ima veliki broj gerlandi valjaka. Obično je veliki broj valjaka potiče od istog proizvođača i istih je tehničkih karakteristika. Kod brojevno složenih sistema se kao dominantan problem modelovanja nameće pitanje vremena kalkulacije pouzdanosti usled velikog broja elemenata Sistema.

Strukturno složeni sistemi imaju raznorodne elemente, tj. možemo reći da oni podležu različitim teorijskim raspodelama pojave otkaza. Kod strukturno složenih sistema postoje problemi prezentovanja strukture sistema i povezivanje velikog broja elemenata sa različitim raspodelama verovatnoće pojave otkaza.

Još jedan značajan aspekt na osnovu kog se mogu podeliti složeni tehnički sistemi jeste popravljivost Sistema. $\mathrm{Na}$ osnovu toga razlikujemo:

- popravljive i

- nepopravljive tehničke sisteme.

Popravljivi sistem je onaj koji se može vratiti u operativno stanje bilo kakvom akcijom održavanja uključujući i zamene i/ili popravke delova sistema. Kada govorimo o stopi po kojoj se pojavljuju otkazi popravljivih sistema, relativno je nepravilno govoriti o intenzitetu otkaza ili hazardu kao indikatoru iz razloga što se on odnosi na vremena prvih otkaza u populaciji nepopravljivih sistema, pa se primenjuje termin Rate Of Occurrence Of Failure (ROCOF) - Intenzitet pojave otkaza ili „intenzitet popravke“. Ipak suština ovih termina je ista jer iako ROCOF predstavlja svojevrsnu suprotnost hazarda, ne dolazi nužno do grešaka u modelovanju i proračunima prilikom nepravilne upotrebe ovih pojmova.

Nepopravljivi sistemi su oni za koje možemo reći da nakon pojave otkaza svaki pojedinačni sistem koji je otkazao biva trajno uklonjen iz upotrebe. 
Složeni tehnički sistemi danas su po pravilu popravljivi, ali se može govoriti o popravljivim i nepopravljivim komponentama sistema ili onima koje se iz raznih praktičnih razloga mogu tako posmatrati (npr. kad se finansijski ne isplati popravljati popravljivu komponentu sistema).

Složeni tehnički sistemi se neretko preventivno održavaju pa veliki broj preventivnih akcija održavanja I posledično mali broj otkaza po komponenti otežava modelovanje pouzdanosti sistema. Na ova pitanja teorija pouzdanosti još nije blizu konačnog odgovora.

\section{OGRANIČENJA MODELOVANJA}

Pouzdanost složenih tehničkih sistema postavlja pitanja izvođenja validnih rezultata pouzdanosti prema modelu u konačnom vremenu. Složeniji modeli koji bi bolje reprezentovali pouzdanost ovakvih sistema su svakako adekvatniji, ali podrazumevaju problematiku prikupljanja podataka i njihovog unosa, validnog reprezentovanja strukture i stanja sistema, reprezentovanje uticaja popravki na pouzdanost kao i problem ograničenog vremena proračuna pa i drugo. Otuda su ozbiljnija hvatanja u koštac sa ovom problematikom novijeg datuma.

Neki od često preporučivanih modela su semiMarkovljevi modeli. Neki pogledi na ovu problematiku odlaze u pravcu modelovanja pouzdanosti na bazi multi-state pristupa dok drugi u pravcu dekomponovanja sistema recimo na bazi blok dijagrama pouzdanosti.

Pretpostavka da je sistem sačinjen od multi-state komponenti sa nivoima pouzdanosti koji opadaju tokom vremena bez mogućeg uticaja opravkama tokom vremena na pouzdanost sistema ima dosta limitirajućih faktora. lako se ovim pristupom može izbeći veoma teška problematika kontinualnih veličina koje se odnose na pouzdanost i time dobiti diskretan oblik prezentovanja pouzdanosti na lak način te i sve jako lako pretvoriti u programski kod koji će dati potrebno vreme izvršenja, ipak prezentovanje pouzdanosti komponenti sistema u samo nekoliko veličina bez uvažavanja gustine verovatnoće pojave otkaza (koja se i ne razmatra) je veoma diskutabilna i slikovito rečeno predstavlja „kroki crtež“ prezentovanja pouzdanosti složenih sistema. Ovo su po pravilu ograničenja modelovanja pouzdanosti kompleksnih tehničkih sistema sa multi-state pristupom.

Neki od modela idu dalje i definišu i strukturu sistema pomoću jednostavnih blok dijagrama ali i uvažavanjem rada sistema sve do otkaza "m“ od „n“ komponenti sistema.

Uzimajući u obzir vremensku dinamiku pouzdanosti pojavljuju se određene teškoće formiranja modela. Naime, potrebno je kontinualne vrednosti teorijskih raspodela $i$ odgovarajućih veličina pretvoriti u adekvatne diskretne a da ne dođe do gubitka suštine premalim brojem vremenskih tačaka kalkulacije ili sa druge strane, do nemogućnosti da se proračun izvede usled velikog broja vremenskih tačaka kalkulacije pouzdanosti.

Nalaženje broja vremenskih tačaka kalkulacije mora uzeti u obzir i dekomponovanje sistema u razmatranje jer je broj proračuna multiplikovan brojem komponenata.

Još jedan bitan faktor su i jedinice mere u kojima se vrši proračun koje ne moraju nužno biti i one u kojima se iskazuju vremena otkaza u bazi podataka.

$\mathrm{Na}$ kraju i broj iteracija simulacije ukoliko se primenjuje Monte Carlo metod je dodatni multiplikator broja proračuna koji se ne sme izostaviti.

Kako se neretko radi o veoma dugim vremenskim periodima kalkulacije potrebno je voditi računa o svim navedenim faktorima na odabir adekvatnog broja vremenskih tačaka kalkulacije.

Kada su u pitanju kompleksni tehnički sistemi koji su popravljivi, kakve srećemo najčešće u industriji i u mali broj do sada razvijenih modela je adekvatan sa aspekta pokrivanja preventivnih akcija održavanja. Ako se uzme u obzir da u realnim uslovima opravke nisu takve da je zamenjeni ili popravljeni deo sistema uvek "dobar kao nov" tj. da mu je pouzdanost uvek 1 onda je broj modela još manji. Još veći nedostatak postojećih modela je taj što gotovo svi uzimaju u razmatranje pouzdanost celovitog sistema a ne pouzdanost pojedinih komponenata i preko njih formirajući pouzdanost celog sistema. Ovo je veoma ozbiljan nedostatak koji ne pruža realnu sliku o stanju sistema i dovodi gotovo obavezno do veoma velikih razlika između procenjene $\mathrm{i}$ stvarne pouzdanosti sistema. Takođe ostaje 
problem malog broja otkaza komponenata kod mnogih sistema ili nepotpunih podataka o otkazima što nije redak slučaj u praksi (Sun, 2006).

Svakako izlišno je pominjati da postoji efikasan, sveobuhvatan i potpuno primenljiv model koji može da uvaži niz preventivnih akcija održavanja, pogotovu koje su imperfektne ili uvažavaju interakciju komponenata uz mali broj otkaza sistema u bazi podataka (Sun, 2006).

\section{RAZVIJENI MODELI}

Kada su u pitanju modelovanja pouzdanosti složenih tehničkih sistema mogu se neka od istraživanja uzeti kao referentna i izložiti njihove karakteristike.

U radu (Dev, Samsher, Kachhwaha, \& Rajesh, 2014) straživao se indeks pouzdanosti elektrane koja je dekomponovana i grafičkom metodom prezentovana. Ovo istraživanje je solidan pokušaj rešavanja krucijalnog problema kod ovakvih složenih tehničkih sistema koji se i preventivno održavaju u smislu da je moguće nadomestiti mali broj podataka o otkazima. Ipak, model se i previše oslanja na empiriju i nema dovoljno objektivne podatke te je moguće primenjivati ga efikasnije na sisteme koji su novi. Sistemi u eksploataciji i sistemi koji se mogu posle dužeg perioda eksploatacije prema otkazima dekomponovati na veći broj komponenti nisu podesni za primenu ovakvog modela pouzdanosti. Jasno je da su sistemi najčešće upravo u periodu eksploatacije. Još i važnije, interakcije otkaza komponenata sistema nisu predviđene modelom. Kao rezultat modela dobija se RTRI - indeks pouzdanosti u realnom vremenu što zapravo predstavlja vrednost pouzdanosti u jednoj vremenskoj tački kalkulacije.

Mnoga istraživanja oslanjajući se na Monte Carlo simulacije, poput istraživanja (Naess, Leira, \& Batsevych, 2009) pokušavaju da zaobiđu probleme matematički kompleksnih ili neotkrivenih pravila modelovanja pouzdanosti. Ovaj metod daje prostora da se takav zadatak uspešno i prevaziđe, ali modelima nedostaju vremenska dinamika i/ili preventivne akcije održavanja. Time su modeli izgubili mogućnosti realne implementacije, naročito kada je potrebno primeniti in na sisteme složenije strukture.
Istraživanje (Weber \& Jouffe, 2006) kombinuje više metoda poput metode analize stabla otkaza, Bajesove mreže i Markovljevih lanaca. Ovo istraživanje je usmereno na modelovanje pouzdanosti proizvodnih procesa kod složenih tehničkih sistema. To znači i veće zahteve u domenu modelovanja pouzdanosti pogotovo jer je ovaj model uvažio postojanje preventivnih akcija održavanja kao i vremensku dinamiku pouzdanosti. Ono što je izostalo od realnih okolnosti jesu interakcije otkaza i mogućnost primene modela na složenih tehnički sistem dekomponovan na veliki broj komponenata usled eksponencijalnog rasta broja kombinacija $u$ modelu te je proračune za pojedine slučajeve nemoguće izvršiti u razumnom vremenskom roku.

(Moazzami, Hemmati, \& Haghighatdar, 2013) su dali procene pouzdanosti sabirnica u elektrani koristeći Monte Carlo simulacije, međutim vremenska dinamika kretanja procenjene pouzdanosti je izostala, a nisu predviđeni ni slučajevi opravki koji imaju realni uticaj na pouzdanost sistema. Takođe, parametarski procenjena pouzdanost je parcijalno sagledavana bez integralnog modela.

U svojoj disertaciji Sun (2006) je razvio nekoliko modela oslanjajući se na postojeće poput SSA i AIMF. Novi razvijeni model je ESSA u koji je involviran slučaj malog broja otkaza sistema, preventivnih akcija održavanja, imperfektnih popravki, interakcije otkaza i vremenske dinamike. Model takođe previđa i postojanje kaskadnih otkaza kao mogućnost primene različitih distribucija otkaza. Model je orijentisan na donošenje odluka o pravovremenim preventivnim, ali ne i korektivnim akcijama održavanja, pa je kombinovano održavanje isključeno iz modela. Model omogućuje da se pouzdanost svake komponente sistema posebno razmatra te $\mathrm{i}$ preventivne akcije održavanja su definisane prema svakoj komponenti sistema zasebno. Interakcije komponenata su definisane matricom interaktivnih koeficijenata pri čemu je uticaj otkaza jedne komponente na otkaz druge komponente konstantan tokom vremena. Nakon preventivnih otkaza komponenata moguća je promena karakteristika teorijske raspodele otkaza a komponente sistema na kojima ne bilo preventivnih akcija održavanja. Ipak, heuristički pristup određivanju koeficijenata interakcije je ostao slaba tačka modela i otežava njegovu 
primenljivost. ESSA model nema jasno iskazane algoritme iako je jasno da in je moguće definisati. Model ima i unapred definisana vremena preventivnih akcija održavanja i primena akcija održavanja prema pouzdanosti nije deo modela iako je to realnost kod održavanja prema pouzdanosti.

U našoj zemlji istraživanje (Petrovic, Marinkovic, \& Marikovic, 2011) je primenom Markovljevog procesa ustanovljeno optimalno preventivno vreme održavanja maksimizacijom raspoloživosti sistema. Model je stohastički i razmatra akcije održavanja i njihove efekte. Model je primenjen transportni sistem koji je dekomponovan na dve komponente. Ovakav model se lako može orijentisati i na pouzdanost njenim kriterijumima pružiti odgovor o vremenima optimalnih akcijama održavanja. Ipak, da bi se primenio i na strukturno kompleksne tehničke sisteme sa velikim brojem komponenata ovaj model bi morao da pretrpi značajne izmene i reši mnoga pitanja. Model takođe ne predviđa ni imperfektne akcije održavanja niti interakciju otkaza komponenti sistema.

\section{PREDIKCIJA SISTEMA SA ODRŽAVANJEM \\ POUZDANOSTI PREVENTIVINIM}

Preventivne akcije održavanja po definiciji imaju za cilj da se izbegne ili odloži otkaz sistema tokom nekog perioda. Ipak nisu sve akcije održavanja jednako efikasne niti uvek ostvaruju cilj zbog koga se izvode. Preventivno održavanje označava i popravke i/ili zamenu delova sistema. Kompleksni sistemi se uobičajeno sastoje iz nekoliko komponenata (podsistema) pri čemu svaka od njih ima različit životni ciklus i distribuciju otkaza. Ukoliko na ovim sistemima postoje preventivne akcije održavanja, one se neretko sprovode samo na jednoj ili nekim od ovih komponenti sistema. Svakako cilj svake od preventivnih akcija održavanja je da se nivo pouzdanosti podigne na što viši nivo te se sva strategija održavanja uvek i okreće ka kreiranju optimalnih odluka za dostizanje ovog cilja. Stoga je kod popravljivih sistema u centru današnjih istraživanja pitanje predikcije pouzdanosti i iznalaženja optimalne strategije održavanja. Ipak, kao i uvek svaki od modela koji su razvijeni u cilju predikcije pouzdanosti sistema ima svoja ograničenja i umanjuje njihovu primenljivost pa je prostor za istraživanje u ovoj oblasti širok. (Sun, 2006)

Svakako da je prvi ozbiljan nedostatak u ovakvim modelima upravo to da stanja sistema nisu dovoljno dobro opisana. Recimo da se u većini modela sve svodi na stanja poput "dobro kao novo" i "loše kao staro". Neki drugi su limitirani na to da popravke i ne uzrokuju promene pouzdanosti sistema (npr. NHPP model) dok drugi nakon popravke počinju da celi sistem gledaju kao nov - iz početka, što takođe ne odgovara realnosti. Ovo, dakle, nameće potrebu da se u model uvrsti postojanje imperfektnih akcija održavanja koje mogu da se odraze šaroliko na pouzdanost čak i pojedine komponente sistema što je upravo odgovarajuće realnim događajima u industriji. $U$ tom smislu je moguće očekivati dva scenarija imperfektnih akcija održavanja. Prvi scenario je da se nakon akcije održavanja pouzdanost sistema ne vrati na početnu vrednost. To je moguće očekivati kada se nakon otkaza ili pre njega samo pojedine komponente sistema popravljaju a druge ne. Drugi je da se pouzdanost sistema vrati na vrednost 1 ali dolazi do bržeg pogoršanja stanja sistema nego pre, što će reći da je hazard sistema nakon akcije održavanja postao veći. Naravno postoji i treći scenario koji može biti kombinacija prva dva. Dakle ovo se pitanje svodi na razvoj modela koji podrazumeva višestruke preventivne imperfektne akcije održavanja. Ovakav model nije još razvijen za tehničke sisteme koji su predmet ovog istraživanja. lako postoje modeli koji omogućuju ovakvo modelovanje pouzdanosti njihov čest glavni nedostatak je što traže procenu od strane inženjera na kom je nivou pouzdanost komponenata sistema nakon opravke što je veoma nesigurna i loša polazna osnova modela. Još veći nedostatak je svakako posmatranje sistema kao celovitog i kao crne kutije bez njegovog dekomponovanja, te dobijanja realnije procene pouzdanosti. Dobar broj modela je razvijan i na stohastičkim osnovama, ali je problem kod njih kompleksnost i samim tim teža primenljivost. Oni često traže više simuliranja zasnovanih na slučajnim varijablama radi dobijanja validnijih rezultata ali je svakako veći problem upravo to što se tada rapidno povećava vreme proračuna te je model teško primeniti. Ako se još u obzir uzme potreba za dekomponovanjem sistema koja je prethodno izneta primenljiv model 
izgleda gotovo nemoguće napraviti za kompleksne tehničke sisteme. Zato se češće odlazi u pokušaje da se modeli realizuju preko kalkulacija MTTF ili očekivanog broja otkaza7 nego li nađe uticaj preventivne opravke na pouzdanost komponenti sistema iako je jasno da drugi način modelovanja omogućuje kvalitetnije informacije. Takođe, modelovanje sa predefinisanim vremenom preventivnog održavanja ima smisla mnogo puta, ali je sa druge strane za veliki broj sistema potpuno neprimenljivo. (Sun, 2006)

U narednom poglavlju je prikazan model SSA koji je prilagođen uvršćivanjem imperfektnih opravki kao model koji popravlja najveći broj prethodno iznetih ograničenja ali i pored toga ima nedostatke a naročito po pitanju primenljivosti na složene tehničke sisteme.

\section{PREDIKCIJA}

POUZDANOSTI SISTEMA SA ODRŽAVANJEM PREVENTIVINIM

Ovaj model uzima kao polaznu osnovu da razdvaja popravljive i nepopravljive komponente sistema, te procenjuje pouzdanost komponenti sistema odvojeno ne posmatrajući sistem isključivo celovito pa otuda u nazivu split podeljen. On predstavlja proširenje Ebelingovog metoda u smislu uzimanja u obzir imperfektnih popravki (Sun, 2006).

Pretpostavke ovog sistema su:

- Svi otkazi su međusobno nezavisni a popravke na popravljivim komponentama sistema ne utiču na pouzdanost nepopravljivih.

- Funkcije pouzdanosti i novih i popravljanih komponenata su poznate. Postoje razvijene metode da se na osnovu postojećih podataka o otkazima dođe do funkcija pouzdanosti pa je moguća primena različitih.

- Blok dijagram sistema je poznat kao i to koje su komponente popravljive a koje ne.

- Vreme popravke je neznatno i irelevantno za proračun pouzdanosti.

- Vreme preventivne akcije održavanja je unapred determinisano.
Modelovanje pouzdanosti je zadatak koji najčešće ne bude adekvatno obavljen iz razloga što većina modela ne bude primenljiva ili ne uvažava realno stanje stvari. Upravo između ova dva uslova se nalazi uspeh modelovanja pouzdanosti. Uvažavanjem prevelikog broja realnosti stvara se kompleksan i neprimenljiv model. Sa druge strane, simplifikovanje modela radi njegove primenljivosti vodi do neupotrebljivosti modela sa aspekta da ne pruža validne i upotrebljive podatke o pouzdanosti. Iz ovog razloga postoji dosta različitih polazišta kod modelovanja $i$ od toga $i$ zavisi puno daljih postupaka modelovanja koji su ishođeni polazištima. Neke od postojećih modela je moguće odmah primenjivati dok je druge potrebno prilagođavati konkretnom sistemu. Ukoliko su te modifikacije manjeg obima model može biti univerzalniji i primenljiviji na veći broj sistema, ali sa druge strane postoji mogućnost da ne odgovara konkretnom tehničkom sistemu.

U svoj potrazi za adekvatnim ravnotežnim odnosom među kriterijumima kako bi se iznašao pravi model potrebno je stvoriti pretpostavke o karakteristikama sistema, načinima održavanja, parametrima koji će se uzimati u obzir i o svemu što može uticati na model, kao i odabrati početno polazište $u$ nekom od postojećih modela te prilagoditi ga konkretnom tehničkom sistemu. Dodatni prostor za kreiranje modela daje primena kompjuterskih tehnologija. Ona je pogotovu korisna u slučajevima masovnih proračuna koji su neizbežni kod kompleksnih tehničkih sistema kao i kod numeričkog rešavanja matematičkih proračuna koji se ne mogu obaviti jednostavno ili su nerešivi. Još jedno polje primene računara su i simulacije koje se uvek mogu pokazati korisnim i pogotovu onda kada se traga za pravilima $u$ mnoštvu pojedinih slučajeva kao i validaciji dobijenih rezultata. Kao polazna osnova i uvek korisna, primenljiva i dostupna tehnika za modelovanje pouzdanosti se može koristiti Monte Carlo simulacija (Dekker \& Groenendijk, 1995).

Model koji se može uzeti kao početno polazište daljeg istraživanja je SSA model zbog svoje osobine da sistem ne posmatra celovito već ga dekomponuje kao i da poznaje razliku između popravljivih i nepopravljivih komponenti sistema. 
SSA model možemo razmatrati u nekoliko mogućih scenarija. Prvi je radi lakšeg razumevanja kada se samo jedna komponenta smatra popravljivom, a sve ostale nepopravljivim u sistemu. Popravljivu ćemo nazvati komponentom 1. Strategija održavanja je bazirana na pretpostavci da kada nivo pouzdanosti čitavog sistema padne na nivo $R_{0}$ tada se akcijom održavanja na popravljivoj komponenti sistema povećava nivo pouzdanosti. Dakle, radi se o sistemu sa minimalnim potrebnim nivoom pouzdanosti koji se želi održavati. Pretpostavimo radi preglednosti da je upravo komponenta 1 kao popravljiva najsklonija otkazivanju. Prvi slučaj koji možemo razmatrati jeste slučaj redne veze između komponente 1 i ostatka sistema (PodS) koji sadrži nepopravljive komponente (slika 1.).

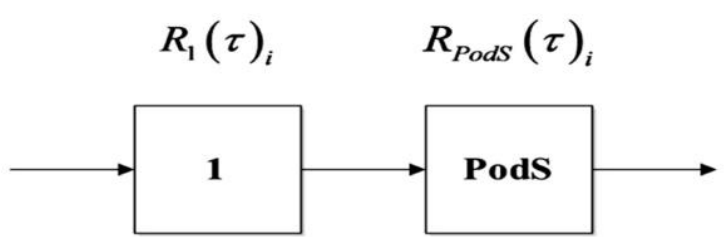

Slika. 1 Redna veza popravljive komponente $i$ nepopravljivih komponenata kompleksnog sistema

$R_{1}(\tau)_{1}$ je pouzdanost komponente 1 posle vremena proteklog od poslednje i-te preventivne akcije održavanja. Dakle, na početku je $i=0$. Uobičajena situacija u industriji je da sistem nakon akcije održavanja nije "dobar kao nov" tj. da nema pouzdanost na nivou $R_{s}=1$, a to je postojanjem popravljivih i nepopravljivih komponenti ispunjen uslov koji se na ovom primeru jasno može videti na slici 2.

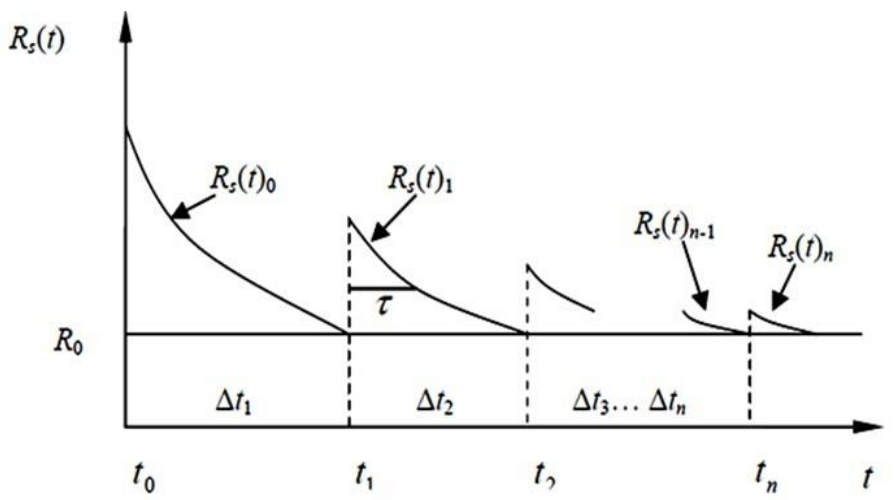

Slika. 2 Kretanje pouzdanosti imperfektno popravljanog kompleksnog sistema

Na slici 2. $\Delta t_{i}$ predstavlja interval vremena između $(i-1)$ i $i$ - te opravke sistema. Tada je ukupno operativno vreme sistema.

$t=\sum_{i=1}^{n} \Delta t_{i}+\tau$

a ukupna pouzdanost sistema je

$R_{S}(\tau)_{i}=R_{1}(\tau)_{i} R_{\text {PodS }}(\tau)_{i}$

gde je $i=0,1,2, \ldots, n$.

Dakle, početni nivo pouzdanosti sistema je $R_{S}(\tau)_{0}=R_{1}(\tau)_{0} R_{\text {Pods }}(\tau)_{0}$, a preventivna akcija održavanja se preduzima onog trenutka kada pouzdanost sistem dođe na minimalno potrebnu tj. kada je $R_{S}(\tau)_{i}=R_{0}$ i tada se pouzdanost sistema povećava preventivnom opravkom popravljive komponente 1 dok druge - nepopravljive komponente sistema, ostaju na istom nivou pouzdanosti. Ukupni efekat na pouzdanost sistema nakon $i$ - te opravke sistema bi se mogu iskazati kao
$R_{S}(\tau)_{0}=R_{1}(\tau)_{0} R_{\text {PodS }}(\tau)_{0}$

gde je $i=0,1,2, \ldots, n$ broj preventivnih opravki. (Sun, 2006)

Nakon $n$ preventivnih akcija održavanja pouzdanost sistema bi se mogla proceniti kao:

$R_{S}(\tau)_{n}=R_{1}(\tau)_{n} R_{\text {Pods }}\left(\tau+\sum_{i=1}^{n} \Delta t_{i}\right)_{0}$

te ako je operativno vreme $t=\tau+\sum_{i=1}^{n} \Delta t_{i}$ možemo napisati da je:

$R_{S}(\tau)_{n}=\frac{R_{1}\left(t-\sum_{i=1}^{n} \Delta t_{i}\right)_{n} R_{S}(t)_{0}}{R_{1}(t)_{0}}$

gde je $R_{S}(t)$ pouzdanost sistema nakon $n$ preventivnih akcija održavanja. (Sun, 2006)

Drugi slučaj koji možemo razmatrati jeste slučaj paralelne veze između komponente 1 i ostatka sistema (PodS) koji sadrži nepopravljive komponente (slika 3.) (Sun, 2006). 


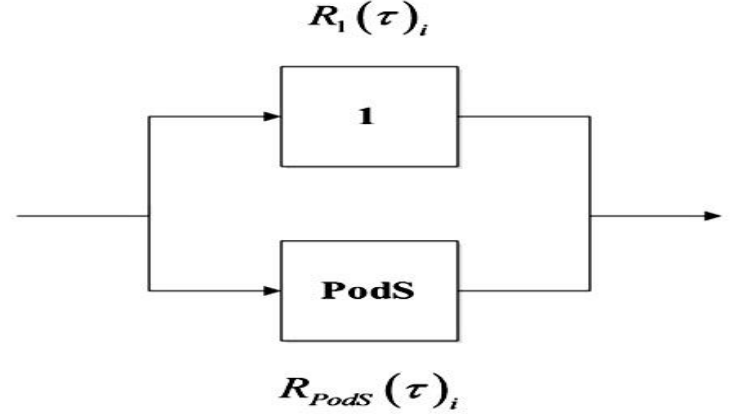

Slika. 3 Paralelna veza popravljive komponente $i$ nepopravljivih komponenata kompleksnog sistema

Tada važi relacija:

$R_{S}(\tau)_{i}=R_{1}(\tau)_{i} R_{\text {PodS }}(\tau)_{i}, i=0,1,2, \ldots, n$.

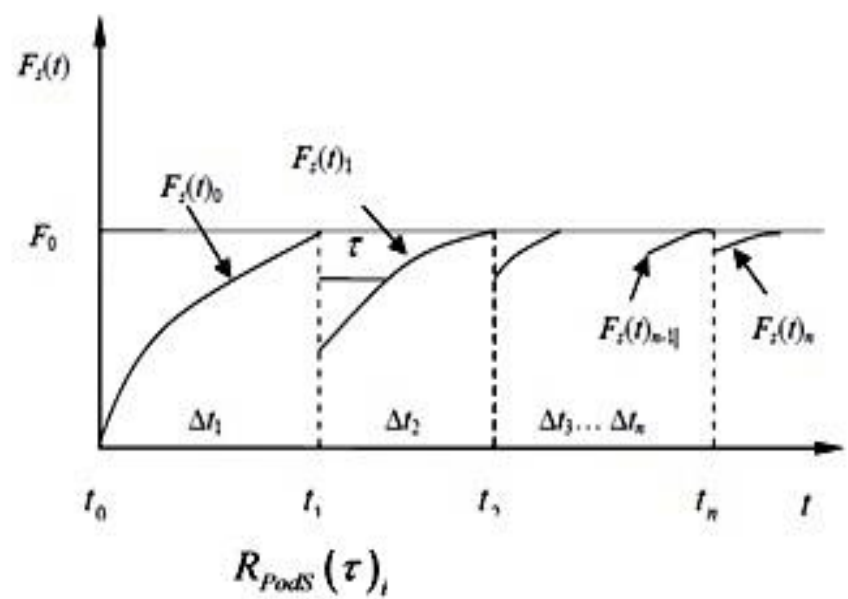

Slika. 4 Kretanje nepouzdanosti imperfektno popravljanog kompleksnog sistema

Generalno je uočljivo da nepouzdanost tokom vremena raste pri svakoj narednoj preventivnoj akciji održavanja što je odraz imperfektnih akcija održavanja.
Ekvivalentno je moguća napisati i sledeću relaciju:

$F_{S}(\tau)_{i}=F_{1}(\tau)_{i} F_{\text {Pods }}(\tau)_{i} i=0,1,2, \ldots, n$.

Analogno svemu prethodno napisanom 0 pouzdanosti redno vezanih komponenata sistema može se izvesti sledeća jednakost:

$F_{S}(\tau)_{n}=\frac{F_{1}(\tau)_{n} F_{S}\left(\tau+\sum_{i=1}^{n} \Delta t_{i}\right)_{0}}{F_{1}\left(\tau+\sum_{i=1}^{n} \Delta t_{i}\right)_{0}}$

gde je $F_{S}(\tau)_{n}$ nepouzdanost sistema nakon $n$-te preventivne akcije. Funkcije $F_{1}(\tau)_{0}$ i $F_{1}(\tau)_{n}$ predstavljaju nepouzdanosti komponente 1 pre preventivnih akcija i posle $n$-te preventivne akcije održavanja., respektivno, a $F_{S}(\tau)_{0}$ je nepouzdanost celog sistema. Slika 4. prikazuje kretanje nepouzdanosti sistema tokom vremena.
Sledeći scenario je više serijskih popravljivih komponenti, gde je m popravljivih komponenti, a ostale čine podsistem nepopravljivih komponenti (slika 5.).

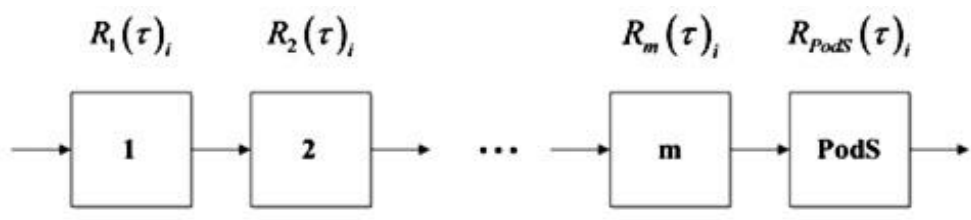

Slika. 5 Sistem sa m serijskih popravljivih komponenti (Sun, 2006)

Kada je u pitanju složenija struktura sistema, koja se svakako sastoji od kombinacije već pomenutih redno ili paralelno vezanih komponenata sistema, proračun pouzdanosti nije ni najmanje jednostavan u svetlu vremenske dinamike. Upravo ona usložnjava proračun i otežava izvodljivost proračuna. Heuristički pristupajući problemu, hipotetički se rešenje ovog problema može opisati u nekoliko koraka, ali ovo svakako nije potpuno rešenje kod složenih struktura već predstavlja idejno rešenje koje svoju primenljivost tek mora naći u konkretnim slučajevima. Taj niz koraka se može predstaviti kao za SSA model se može iskazati putem sledećih koraka:

- Prikupljanje podataka o otkazima.

- Dekomponovanje sistema i izrada blok dijagrama pouzdanosti sa definisanjem popravljivih i nepopravljivih komponenti sistema. 
- Određivanje pouzdanosti svake komponente posebno i celog sistema na bazi blok dijagrama.

- Određivanje prvog vremena preventivne akcije i komponenti koje će biti popravljane u toj preventivnoj akciji održavanja na bazi funkcija pouzdanosti celog sistema i njegovih komponenti.

- Proračun pouzdanosti svih komponenti i celokupnog sistema na bazi blok dijagrama.

- Određivanje prvog vremena preventivne akcije i komponenti koje će biti popravljane u toj preventivnoj akciji održavanja na bazi funkcija pouzdanosti celog sistema i njegovih komponenti.

- Ovaj postupak se ponavlja iterativno sve dok je to potrebno.

\section{ZAKLJUČAK}

Kao zaključak može se izvesti da je složena problematika modelovanja pouzdanosti složenih tehničkih sistema u industriji najzahtevnija u domenu implementacije na brojevno složene sisteme. Nasuprot tome, da bi se došlo do kvalitetnijih podataka o pouzdanosti sistema potrebno je dekomponovanje sistema na veći broj komponenti čemu se kao ograničenje nameće neretko mali broj podataka o otkazima po komponenti. SSA koncept ima dobre osobine uz sve nedostatke kao I svaki model.

\section{Prednosti ovog modela su:}

- Za razliku od većine primenjivanih modela koji se oslanjaju na unapred određeno vreme preventivnih akcija održavanja, MTTF ili očekivanog broja otkaza, ovaj model je puno podesniji za dugi period operativnog vremena sistema i promene odluka o preventivnim akcijama održavanja kakve su česta pojava u realnosti i kojima se menjaju veličine poput MTTF ili očekivanog broja otkaza.
- Model je sposoban da da uvid u kretanje pouzdanosti pojedinačnih komponenti i njihov uticaj na ukupnu pouzdanost sistema.

- U model je moguće implementirati i imperfektne opravke poput onih koje su karaktera "dobro kao novo", "lošije od novog", "loše kao staro", "bolje nego novo" itd.

- Nema ograničenja po pitanju teorijske raspodele otkaza koja se može primeniti na model.

Nedostaci ovakvog pristupa su:

- Veoma teška primena modela za slučaj velike složenosti sistema po broju komponenata ali i nedovoljno dobra slika o pouzdanosti sistema za slučaj da se on slabo dekomponuje. Ipak, ukoliko sistem nema veliki broj otkaza onda dekomponovanje nije nužno u takvoj meri a dominantan problem modelovanja postaje mali broj otkaza.

- Takođe, ukoliko bi postojale interakcije komponenata sistema u smislu da otkaz jedne utiče na pouzdanost druge komponente sistema, došlo bi do krajnje ozbiljnih i grubih grešaka proračuna,

- Model ne uvažava korektivne akcije održavanja niti pruža mogućnost uvida u broj mogućih otkaza sistema, tj. komponenti.

Jasno je da je ovaj model potrebno unaprediti po pitanjima u kojima ima nedostataka. Nedostatak primenljivosti se može rešavati aproksimacijama kao i primenom kompjuterskih tehnologija kako bi se vreme proračuna skratilo za sisteme sa velikim brojem komponenata. Pitanje postojanja otkaza i posledica koje se dešavaju na pouzdanost same komponente se može rešiti simulacijama putem kojih se može doći do uvida u to šta se dešava sa pouzdanošću sistema na velikom broju otkaza i izvlačenjem zaključaka na osnovu dovoljno velikog broja simulacija pouzdanosti sistema. $\mathrm{Na}$ kraju, pitanje interakcija komponenata nakon pojave otkaza u smislu uticaja na pouzdanost drugo je pitanje koje se mora detaljnije rešavati.

\section{CITIRANI RADOVI}

Dekker, R., \& Groenendijk, W. (1995). Availability assessment methods and their application in practice. Microelectronics Reliability, 35(9-10), 1257-1274.

Dev, N., Samsher, Kachhwaha, S. S., \& Rajesh, A. (2014). Development of reliability index for combined cycle power plant using graph theoretic approach. Ain Shams Engineering Journal, Ain Shams University, 5(1), 193-203. 
Moazzami, M., Hemmati, R., \& Haghighatdar, F. (2013). Reliability evaluation for different power plant busbar layouts by using sequential Monte Carlo simulation. Electrical Power and Energy Systems, 53, 987-993.

Naess, A., Leira, J. B., \& Batsevych, O. (2009). System reliability analysis by enhanced Monte Carlo simulation. Structural Safety, 31(5), 349-355.

Petrovic, G., Marinkovic, Z., \& Marikovic, D. (2011). Optimal preventive maintenance model of complex degraded systems: A real life case study. Journal of Scientific \& Industrial Research, 70(6), 412-420.

Sun, Y. (2006). Reliability Prediction Of Complex Repairable Systems: An Engineering Approach. Faculty of Built Environment and Engineering, University of Technology: University of Technology.

Weber, P., \& Jouffe, L. (2006). Complex system reliability modelling with Dynamic Object Oriented Bayesian Networks (DOOBN). Reliability Engineering and System Safety, 91(2), 149-162.

Datum prve prijave:

Datum prijema korigovanog članka:

Datum prihvatanja članka:
23.03.2016.

03.09.2016.

23.12.2016.

Kako citirati ovaj rad? / How to cite this article?

Style - APA Sixth Edition:

Milošević, D. A. (2017, January 15). Modelovanje pouzdanosti složenih tehničkih sistema u industriji, SSA koncept. (Z. Cekerevac, Ed.) FBIM Transactions, 5(1), 80-89. doi:10.12709/fbim.05.05.01.08

Style - Chicago Sixteenth Edition:

Milošević, Dragan A. "Modelovanje pouzdanosti složenih tehničkih sistema u industriji, SSA koncept." Edited by Zoran Cekerevac. FBIM Transactions (MESTE) 5, no. 1 (January 2017): 80-89. doi:10.12709/fbim.05.05.01.08.

Style - GOST Name Sort:

Milošević Dragan A. Modelovanje pouzdanosti složenih tehničkih sistema u industriji, SSA koncept [Journal] // FBIM Transactions / ed. Cekerevac Zoran. - Belgrade - Toronto : MESTE, January 15, 2017. - 1 : Vol. 5. - pp. 80-89.

Style - Harvard Anglia:

Milošević, D. A., 2017. Modelovanje pouzdanosti složenih tehničkih sistema u industriji, SSA koncept. FBIM Transactions, 15 January, 5(1), pp. 80-89.

Style - ISO 690 Numerical Reference:

Modelovanje pouzdanosti složenih tehničkih sistema u industriji, SSA koncept. Milošević, Dragan A. [ed.] Zoran Cekerevac. 1, Belgrade - Toronto : MESTE, January 15, 2017, FBIM Transactions, Vol. 5, pp. 80-89. 